\title{
'Para mim, o importante é o público': Entrevista com Frédéric Bonnaud, diretor da Cinémathèque française
}

\author{
Mickaël Robert-Gonçalves \\ Université Sorbonne Nouvelle (LIRA) / Universidade de Coimbra (CEIS20) \\ mickael.robertgoncalves@gmail.com \\ https://orcid.org/0000-0003-2534-8823
}

RESUMO Frédéric Bonnaud é diretor da Cinémathèque française desde 2016. Antes disso, foi jornalista e crítico de cinema. Durante a entrevista realizada a 20 de Janeiro de 2021 numa Cinémathèque française vazia de espectadores e privada do som dos seus projetores, Bonnaud falou da sua relação com essa instituição, o cinema e a cinefilia. Generoso e otimista, abordou os projetos e desafios da Cinémathèque française para os próximos anos, refletindo, ao mesmo tempo, sobre a particular situação de crise que as profissões ligadas ao cinema estão a atravessar.

PALAVRAS-CHAVE Frédéric Bonnaud; Cinémathèque française; COVID-19; digitalização de filmes; exposições; história do cinema.

Em Janeiro de 2021, num contexto de crise sanitária sem precedentes, a Cinémathèque française, muitas vezes considerada como um templo de cinefilia, estava ainda fechada, o que deixava num grande desespero o seu diretor, Frédéric Bonnaud. Apesar disso, o diretor aceitou o convite para explicar a sua relação com a cinefilia, através da sua paixão por festivais de cinema e pela crítica cinematográfica. Desde a sua chegada à Cinemateca Francesa, em 2016, Frédéric Bonnaud tem seguido os passos dos seus antecessores, mas também tem procurado impor a sua própria visão de uma cinemateca moderna. Para tal, reafirmou a sua intenção de atrair cada vez mais pessoas para a Cinémathèque, não só nas salas de exibição, mas também online, através de uma plataforma que foi lançada em 2020 e de um programa 
de exposições únicas. As questões da digitalização ${ }^{1}$ das coleções, o futuro de um museu dedicado ao cinema, bem como a relação com os novos média, como as plataformas de streaming, são também levantadas nesta entrevista inédita.

\section{Mickaël Robert-Gonçalves - Talvez pudéssemos começar por falar da sua carreira profissional, em particular da sua relação com o cinema e a Cinémathèque française?}

Frédéric Bonnaud - De um ponto de vista profissional, comecei a trabalhar em instituições. Primeiro no INA, numa posição extremamente subalterna; depois, na Cinémathèque, numa posição igualmente subalterna, no início dos anos 90. ${ }^{2}$ Assim, conheço a Cinémathèque por dentro há muito tempo. Eu costumava lá ir, embora, como muitos cinéfilos parisienses, deva ter visto tantos, se não mais filmes nos teatros do Quartier Latin e, em particular, no Studio Action. Conheço as atividades desta casa. Sei como é digitalizado um filme. Também sei um pouco como manusear a película, por exemplo. O meu grande pesar é não saber como projetar. Para isso, teria de passar um ou dois meses com um operador... Mas sei como usar uma mesa de montagem; não é muito difícil. Bem, mesmo de um ponto de vista técnico - não sou de todo técnico, nunca fiz um estágio num laboratório, não sou restaurador de filmes, para o dizer de alguma forma -, mas, também, não podem gozar comigo. Sei do que estou a falar. Em suma, os arquivos são um ambiente que conheço bem... Fui jornalista a partir de 1995, quando Les Inrockuptibles ${ }^{3}$ se tornou num semanário. Fi-lo durante vinte anos. Serge Toubiana, ${ }^{4}$ que era talvez menos jornalista do que eu, tinha dirigido uma revista, não um jornal: Les Cahiers du cinéma é uma revista, enquanto que Les Inrocks é um

\footnotetext{
${ }^{1}$ A digitalização, nesta entrevista, é definida tanto como um processo técnico como um método de arquivo. O processo de digitalização é a conversão de informação de um suporte de filme em dados digitais. Para um arquivo como a Cinémathèque française, refere-se também à conversão em massa de documentos em ficheiros informáticos.

${ }^{2}$ Desde 1975, o Instituto Nacional do Audiovisual (INA) é responsável pelo arquivo das produções audiovisuais e pela sua difusão junto do público. O INA também realiza cursos de formação destinados a desenvolver e transmitir conhecimentos nos campos do audiovisual, dos meios de comunicação e do digital.

${ }^{3}$ Les Inrockuptibles, também conhecido como Les Inrocks, é um jornal francês fundado em 1986 e inicialmente dedicado ao rock. Desde então, tornou-se um jornal cultural e político.

${ }^{4}$ Serge Toubiana (n. 1949) é um jornalista e crítico de cinema francês. Juntou-se aos Cahiers du Cinéma em 1972 e participou com Serge Daney na transformação da revista: o cinema foi recolocado no centro de interesse após um período de forte politização (maoísta). Permaneceu nos Cahiers até 1981, quando entrou para o jornal Libération. Foi diretor da Cinémathèque française entre 2003 e 2015.
} 
jornal. Portanto, havia um crítico de cinema a dirigir esta casa. Quando Serge anunciou a sua partida, após quinze anos de bom e leal serviço, eu candidatei-me e fui escolhido. Serge tem sido extremamente útil e o seu balanço é realmente muito bom. Instalou a Cinémathèque em Bercy, ${ }^{5}$ o que não era um dado adquirido, acabou por pacificar as relações com o CNC, tirou-nos do velho e doloroso folclore da Cinémathèque française...

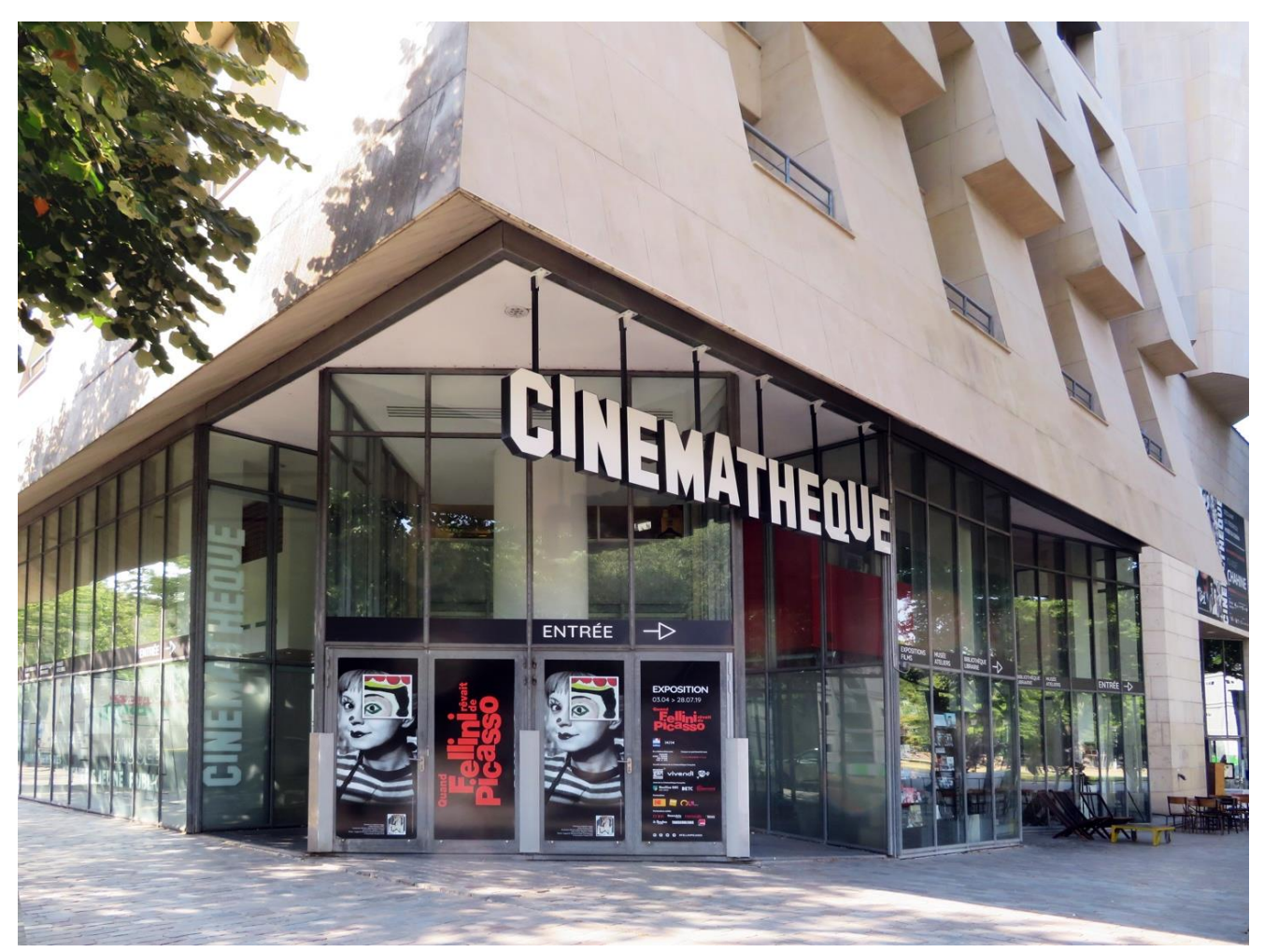

Imagem 1: Cinémathèque française no $\mathrm{n}^{0} 51$ da rue de Bercy, no $12^{\circ}$ arrondissement de Paris. | (c) Zagass Design.

${ }^{5}$ A Cinémathèque française, fundada em 1936, esteve sediada em diferentes locais durante a sua história. Desde 2005, está localizada no distrito de Bercy, no leste de Paris, num edifício projetado pelo arquiteto Frank Gehry, em 1994, para o Centro Americano.

aniki Entrevistas | Interviews 


\section{MRG - Precisamente, em relação a Serge Toubiana e aos Cahiers $d u$ cinéma, referiu a relação com a crítica de cinema. Também foi crítico?}

FB - Sim, sim, eu só fiz críticas cinematográficas entre 1995 e 2002. Fui, puramente, um crítico.

\section{MRG - Nos Inrocks?}

FB - Foi principalmente nos Inrocks. Um pouco no Libé. ${ }^{6}$ Devo ter escrito uma ou duas vezes na Trafic... ${ }^{7}$ Foi principalmente nos Inrocks entre 1995 e 2002, mas escrevi muito, intensamente. E eu estava farto disso, francamente.

\section{MRG - Porquê?}

FB - Porque, a certa altura, torna-se rotina e passa-se a vida em projeções de imprensa. Penso que não é que não sejamos suficientemente simpáticos com os filmes, mas que somos demasiado simpáticos com eles... E eu dei muito em sete anos. Acho que me queimei um pouco. Escrevi muito. Fiz centenas de horas de entrevistas, transcrevi centenas de horas. Já estava farto, era demasiado. Olhando para trás, a minha exasperação não se justificava, mas, tendo dito isto, não me arrependo de ter parado. Não me conseguia ver a fazer isso durante toda a minha vida. Aproveitei muito e fui a todos os festivais. Consegui que os Inrocks fossem comigo. Não era de todo a sua tradição; é normal, eles não vinham de lá. Assim, começámos a ir aos festivais. Fomos a todo o lado e eu não estava sozinho: Serge Kaganski ${ }^{8}$ era o líder. Com Serge, colocámos os Inrocks no mapa da crítica cinematográfica em França e, talvez presunçosamente, um pouco na Europa, porque fomos muito a Portugal, a Itália, etc. Fizemos com que as pessoas compreendessem que esse jornal mensal, e depois quinzenal, de música se tinha tornado num verdadeiro semanário cultural, com uma grande parte dedicada ao cinema. E, para responder à sua pergunta, digamos, para simplificar, que havia, de facto, um "gosto Cahiers". Tenho um "gosto Cahiers" heterodoxo, o que significa que adoro criticar o meu próprio gosto, mas ainda tenho um "gosto Cahiers"

\footnotetext{
${ }^{6}$ Libération é um importante jornal diário francês, fundado em 1973.

${ }^{7}$ Trafic é uma revista trimestral francesa dedicada ao cinema, fundada por Jean-Claude Biette e Serge Daney em 1991.

${ }^{8}$ Serge Kaganski (n. 1959) é um jornalista francês, crítico de rock e crítico de cinema, que passou grande parte da sua carreira nos Inrockuptibles.
} 
básico. Não o nego de forma alguma. Ou seja, se odeias Godard, Straub e Oliveira, é difícil falar comigo! Isso foi divertido. Isso foi ótimo com os Inrocks. Adorávamos Tarantino - e ainda adoro Tarantino ou Scorsese, que eram os dois grandes cineastas americanos do momento, que ainda o são, de facto -, mas é verdade que, com Serge, foi bastante natural que tenhamos seguido Oliveira, que tenhamos ido entrevistar Jean-Marie Straub e que estivéssemos obcecados por Godard. Nisso, é verdade, não mudei muito... Por fim, tenho a pretensão de pensar que não sou um sectário. Tenho um "gosto Cahiers" desde o início, mas não sou um sectário.

MRG — Les Inrocks é um jornal que vem da música, com o seu lado de cultura pop. Talvez seja isso que faça com que tenha precisado de uma maior abertura?

FB - Não, não tem nada a ver com Les Inrocks. Sou eu. Por exemplo, Serge, que ainda é o meu melhor amigo, não está de todo interessado pelo Louis de Funès. ${ }^{9}$ Sou eu quem está interessado. Les Inrocks não estavam de todo interessados; estavam realmente interessados no pop.

MRG — Mas isso confirma o seu lado não sectário...

FB - Sim, absolutamente. Por exemplo, estou interessado em fazer coisas que não são necessariamente minhas. Quando faço uma retrospetiva integral de Godard, é minha iniciativa. Não tenho qualquer dificuldade em fazê-lo. Faço-o naturalmente, mas diverte-me e interessa-me quebrar um pouco as expectativas e fazer uma exposição sobre Louis de Funès ou fazer retrospetivas que não são necessariamente esperadas. Penso que a Cinémathèque ainda tem muitos progressos a fazer para ser menos intimidante. Continuamos a ser demasiado intimidantes e não gosto disso. Nunca gostei disso. Tenho um gosto pelo cinema que poderia ser descrito como radical, forte, preciso, mas não gosto da intimidação cultural.

\section{MRG - Como o explica? É pessoal ou está relacionado com algo mais?}

\footnotetext{
${ }^{9}$ Louis de Funès (1914-1983) foi um dos mais populares atores cómicos do cinema francês desde os anos 60 até aos anos 80. Muitos dos seus filmes foram grandes êxitos tanto nos cinemas quanto nas transmissões televisivas, tais como Le gendarme de Saint-Tropez (O Gendarme de Saint-Tropez, 1964) e as suas cinco sequelas, a trilogia Fantômas (1964 a 1967), Le Corniaud (O Oportunista, 1965), La Grande Vadrouille (A Grande Paródia, 1966), Les Aventures de Rabbi Jacob (As Loucas Aventuras do Rabbi Jacob, 1973) e La Soupe aux choux (Encontro com os Extra-Terrestres, 1981).
} 
FB - É completamente pessoal. O cinema é bonito porque é variado... Eu não esperei pelo sucesso do Campeonato do Mundo de 98 para ficar apaixonado por futebol. Tenho um pé na alta cultura, digamos, e um pé na cultura popular de uma forma muito natural, como muita gente, só que agora é muito mais fácil de o dizer. Sempre o disse muito facilmente. É chocante. Se me deparo com um episódio de Dallas, vejo... Não me importo de cantarolar uma canção popular.

MRG - Começávamos a falar um pouco sobre a sua relação com a Cinémathèque française. Podemos falar, numa segunda fase, sobre a própria Cinemateca e o seu papel desde a sua nomeação? Como é que se encaixa se já está um pouco em casa?

FB - Para simplificar, cheguei com o desejo de fazer coisas. O que não quer dizer que nada tenha sido feito. Muito tinha sido feito... Cheguei com o desejo, por exemplo, de que o número de espectadores fosse melhor. Não que tenha sido mau, mas poderia ser melhor e ainda pode ser melhor. Cheguei com ideias, projetos e o desejo de continuar a descompartimentação que tinha sido levada a cabo. O programa das exposições estava um pouco vazio, não sabíamos exatamente o que fazer. Havia algumas coisas planeadas, mas havia lacunas, o que era bom para mim! Assim fiz "Goscinny e o cinema". ${ }^{10}$ Por exemplo, “Goscinny e o cinema” não era uma questão natural. É um projeto muito pessoal que eu fiz rapidamente e que correu bastante bem. Foi divertido ver, de repente, um pequeno Astérix desenhado por Uderzo ${ }^{11}$ no programa da Cinémathèque e, dessa maneira, refletir modestamente (mas, ainda assim, divertindo-se) sobre as ligações entre o cinema e a banda desenhada, que são duas artes muito populares. Digo isto modestamente, mas, mesmo assim, foi um pouco um manifesto. Íamos fazer uma exposição sobre Chris Marker, o que está muito bem e é o nosso dever, mas não íamos fazer só isso. Além disso, o próprio Chris Marker adorava a cultura popular... Por isso, o objetivo era trazer um pouco de ar fresco para o programa de exposições, para o tornar suficientemente variado. Sempre fizemos isso, mas eu queria alargar

\footnotetext{
${ }^{10}$ Esta exposição teve lugar na Cinémathèque française de 4 de Outubro de 2017 a 4 de Março de 2018. Foi comissariada por Frédéric Bonnaud, Jean-Pierre Mercier e Aymar du Chatenet. René Goscinny (19261977) foi um escritor e autor de banda desenhada, mais conhecido por criar Astérix com Albert Uderzo, Iznogoud com Jean Tabary, Le Petit Nicolas com Jean-Jacques Sempé, assim como por assegurar os argumentos de muitos dos álbuns Lucky Luke criados por Morris. É um dos autores franceses mais lidos no mundo.

${ }^{11}$ Albert Uderzo (1927-2020) foi um artista de banda desenhada que colaborou com Goscinny em Astérix.
} 
um pouco mais o espectro: é bom trazer coisas que não são lógicas, não fazer sempre a mesma coisa.

MRG - De facto, a exposição “Goscinny e o cinema”, recordo-me, era uma espécie de manifesto ou uma proposta que indicava qual ia ser a linha.

FB - Era uma forma de dizer que René Goscinny, entre os grandes génios do século XX, era um tipo que estava absolutamente repleto de cultura cinematográfica... Que a sua cultura cinematográfica transparece constantemente em todas as bandas desenhadas que escreveu, que o cinema era o seu horizonte pessoal, o seu sonho, que mais ou menos realizou... Por isso, havia uma história para contar. Ou seja, ele era um pouco cineasta, mas, basicamente, não muito. Por outro lado, esteve imerso na cultura cinematográfica durante absolutamente toda a sua vida. Adoro John Ford, mas John Ford visto através dos olhos de Goscinny faz-me realmente rir às gargalhadas. Não creio que seja esse o caso de Jean-Marie Straub (risos), que certamente conhece John Ford melhor do que eu, mas duvido que ele leia Lucky Luke. Mas eu sim.

MRG - É interessante porque também mostra que a Cinémathèque pode propor exposições que não são simplesmente sobre cineastas ou o mundo do cinema, mas também sobre a forma como o cinema tem influência sobre o mundo.

FB - Absolutamente. As exposições são o meio adequado para o fazer. Por outro lado - devo dizer que refleti muito com Jean-François Rauger, ${ }^{12}$ o diretor de programação, sobre isso -, no caso das retrospetivas, continuamos a ser bastante monográficos, porque, quando está feito, está feito. Como diz Godard, agora toda a gente é um autor. Não podemos desfazer isso. Ganhamos demasiado. Não ganhamos facilmente, ganhamos demasiado. Só fazemos monografias, incluindo de pessoas que, afinal de contas, não são necessariamente autores. Mas é assim que as coisas são.

MRG - Acaba de mencionar o trabalho de Jean-François Rauger, mas qual é o seu papel quando chega à Cinémathèque como diretor?

\footnotetext{
${ }^{12}$ Jean-François Rauger (n. 1959) é um crítico de cinema francês, diretor de programação na Cinémathèque française, que escreveu para Les Cahiers du Cinéma e Le Monde, entre outras publicações.
} 


\section{Como se pode propor Goscinny? E como é que o resto da equipa reage?}

FB - Bem, muito bem. Porque conheço Jean-François há muito tempo, desde o início dos anos 90. Ele é um dos meus melhores amigos. Foi ele que me disse: "Devias escrever". Foi ele que me aconselhou a ir bater à porta dos Inrocks. São pessoas com quem mantenho uma relação de amizade e confiança há muito tempo. É o mesmo com Bernard Benoliel, ${ }^{13}$ o pessoal da Cinémathèque, os diretores, etc. Não tinha qualquer razão para ter conflitos com eles. São pessoas que conheço há muito tempo e sabia que tínhamos uma visão comum. Com JeanFrançois, intervenho na programação, mas é ele quem a faz. Estou lá para dizer "porque não o fazemos de novo?" Ele responde-me "é demasiado cedo" ou “já o fizemos”. Há discussões sem fim para saber se Hitchcock deve ser feito a cada dez, doze ou catorze anos. Acabámos de fazer Godard. Penso que o faremos novamente em 2030. Fizemos Godard no início de 2020, pouco antes da pandemia da COVID-19. Nasceu em 1930. Ele é capaz de ainda estar vivo, é capaz de tudo. Portanto, penso que voltaremos a fazer Godard em 2030 e talvez com uma exposição, quer seja eu ou outra pessoa. Há coisas que têm de ser refeitas a toda a hora. É normal, esse é o nosso papel, sabendo que só fazemos trabalhos completos nessas bases. Há algumas pessoas, estamos sempre a dedicar-lhes retrospetivas e a mostrá-las novamente para as novas gerações e para nós próprios. Há que rever muito. E, depois, há outras pessoas que temos de trazer.

\section{MRG - Então, esta dimensão integral defendida por Rauger é algo que permanecerá na Cinémathèque?}

FB - Sim, é um pouco o nosso ADN, a nossa marca registada. Estamos em Paris de qualquer maneira, por isso não pensamos que somos os únicos. Não tenho uma vocação totalitária. Já lhe disse que também venho do Quartier Latin. Há pessoas que trabalham muito bem. JeanMax Causse ${ }^{14}$ e o seu filho François estão sempre na Filmothèque, por exemplo, e, se há alguém com quem estou em dívida, é com ele. Ele

\footnotetext{
${ }^{13}$ Bernard Benoliel (n. 1965) é o diretor da Acção cultural na Cinémathèque française. Entre 2001 e 2005, foi responsável pelo Festival de Cinema de Belfort - Entrevues. Crítico de cinema, publicou artigos em La Revue du cinéma, Les Cahiers du Cinéma e Trafic.

${ }^{14}$ Jean-Max Causse é um expositor e programador que co-fundou com Jean-Marie Rodon (1938-2016) os cinemas Action, uma rede de pequenos cinemas no Quartier Latin de Paris que tem feito muito em prol da cinefilia desde os anos 70 .
} 
mostrou-me centenas de filmes. Por isso, também devemos distinguirnos dos cinemas do Quartier Latin. Não devemos ficar satisfeitos com 4 ou 5 filmes, devemos acompanhá-los com cada vez mais atividades culturais e educativas. Este é o papel de um museu moderno, ou seja, ao contrário do que por vezes se afirma, há muito apoio didático e educacional na Cinémathèque. De facto, em tempos de confinamento, basta, por exemplo, olhar para tudo o que é colocado no Facebook. É quase demasiado: uma avalanche de conferências, masterclasses... Isso é outra coisa que nos distingue. Quando podemos, mostramos filmes. Temos um programa ambicioso. Fazemos muito. Por vezes, encontramo-nos (ou somos criticados) por fazermos demasiadas coisas. É verdade que, por vezes, há três retrospetivas ao mesmo tempo, que todas as salas estão ocupadas... Alguém que frequenta a Cinemateca pode queixar-se - e com razão - de que não sabe onde se dirigir. Há mais profusão do que economia.

MRG - Disse que mexeu um pouco em película, que sabe o que é... Isso influencia a sua relação com os filmes?

FB - Não, é uma relação de espectador. Não tenho uma religião sectária sobre isso, pois conheço alguns diretores de cinematecas... Ou seja, entre uma má cópia e um bom DCP, prefiro o bom DCP. É isso mesmo. Agora, entre uma cópia num estado físico questionável, ou seja, com arranhões ou nódoas, mas de muito boa qualidade fotográfica, e um DCP muito medíocre fotograficamente, prefiro a cópia em película. Percebe o que quero dizer? Obviamente, entre uma cópia desbotada, inteiramente cor-de-rosa, e um DCP, não há nenhuma hesitação escolho o DCP, é óbvio. Além disso, é também o nosso dever. Se nós próprios não utilizarmos a nossa coleção de filmes, quem o fará? Temos dezenas de milhares de filmes. É preciso admitir que, por vezes, as coisas já não são visíveis, pelo que se tornam cópias de conservação. Sabemos que já não podemos tocá-las, temos de o admitir. Por outro lado, importa também saber que, ao contrário do que o mercado afirma, nem todos os filmes do mundo serão digitalizados. É um monte de tretas. Para lhe contar uma anedota, outro dia, Luc Moullet, ${ }^{15}$ que é nosso amigo, disse-nos "Estou a fazer um livro sobre Claude de Givray e creio que a Cinémathèque tem uma cópia de $35 \mathrm{~mm}$ de um filme invisível chamado Une grosse tête (Chega-lhe que ainda mexe!) com

\footnotetext{
${ }^{15}$ Luc Moullet (n. 1937) é um realizador, produtor e crítico de cinema francês.
} 
Eddie Constantine". Eu nem sabia que existia e, por isso, dissemos ao Luc para cá vir. Ele viu o filme e Jean-François e eu vimos Une grosse tête. Vimos uma cópia de exploração de 1961, com arranhões e saltos, mas nunca haverá nada mais porque ninguém irá digitalizar esse filme. Deve ser valorizado e eu diria mesmo que, num mundo ideal - e estamos a trabalhar para construir este mundo -, deve ser digitalizado. É aí que nos encontramos. Por exemplo, fizemos Belle de jour ( $A$ Bela de Dia), que é um dos meus filmes favoritos, com o Studio Canal e os laboratórios Hiventy. O DCP que conseguimos foi a primeira vez, penso eu, que prestámos realmente homenagem e honrámos a fotografia de Sacha Vierny. Já tinha visto o filme inúmeras vezes em 35 mm e na TV, mas nunca tinha visto o filme como Hiventy conseguiu fazer. Além disso, fizemos uma tiragem em $35 \mathrm{~mm}$ : não devemos hesitar. No entanto, Belle de jour é uma obra-prima, vale a pena... Mas, de Tristana, por exemplo, que também é uma obra-prima, só há um mau HD do Studio Canal. Estas coisas acontecem. O filme deve ser tratado. O problema é que a digitalização custa, pelo menos, 50.000 euros. É caro, muito caro. Portanto, temos de continuar a utilizar a película de $35 \mathrm{~mm}$. Em primeiro lugar, porque a qualidade fotográfica de $35 \mathrm{~mm}$ é, por vezes, difícil de igualar, mas nem sempre. Além disso, se não utilizarmos película, ficamos reduzidos a um número de filmes que não é aceitável para uma cinemateca. Finalmente, é necessário porque temos de fazer algo com as nossas coleções. É excelente examinar as coleções para ver que Une grosse tête com Eddie Constantine, bem, não é uma obra-prima, mas não é assim tão mau.

MRG - Precisamente, em relação a isso, nos projetos da Cinémathèque, desde a sua chegada, o que mudou em termos da relação com a restauração e a digitalização? Qual é a sua política?

FB - A política é que não sou tão rígido como alguns dos meus colegas que, basicamente, dizem "35 mm ou nada". Ainda quero $35 \mathrm{~mm}$, mas sou pragmático. Prefiro ver Belle de jour no DCP a que chegámos, enquanto que, no caso do mau HD de Tristana, prefiro encontrar uma cópia de $35 \mathrm{~mm}$ que será como vai ser, de exploração e do período, depende. Na verdade, é: “depende”. Quando se tem um pouco de lucidez e não se faz disso uma questão de princípio, depende. Porque, ao mesmo tempo, é bom que tenhamos o digital, porque se não tivéssemos o digital, o que faríamos?

MRG - Existem grandes projetos em curso?

aniki Entrevistas| Interviews 
FB - O que fiz quando cheguei foi iniciar grandes projetos. Alguns deles eram óbvios, tais como o aumento do público alargando o espectro tanto quanto possível, tornando claro que a Cinémathèque française não era um clube reservado, mas que todos podiam cá vir. Não que isso ainda não tivesse sido feito. Tinha sido feito, por exemplo, a exposição sobre Tim Burton, ${ }^{16}$ que foi um sucesso considerável. Não foram só os membros do clube que vieram... foram quase $400 \mathrm{mil}$ pessoas, o que é muitíssimo. Temos de prosseguir esta política. Depois disso, a primeira coisa que fiz foi colocar sinalética. Ninguém tinha pensado nisso. Agora, temos o nosso nome no edifício. É melhor assim. Depois, há um espaço, o último livre neste edifício, que está literalmente saturado - não resta um centímetro quadrado: é o sétimo andar, que transformei em estúdio de cinema para fazer ateliers pedagógicos. A oferta pedagógica não estava à altura da tarefa. Depois, percebemos que o embrionário Museu Langlois, ${ }^{17}$ no segundo andar, que se chamava "Passion Cinéma" não era satisfatório; não agradou a ninguém, tão-pouco àqueles que o tinham feito. Então, disse a mim próprio que íamos conseguir fazer um verdadeiro museu de cinema. Vamos retomar essa ideia mais tarde, talvez num lugar fora de Paris, mas, por enquanto, fizemos o museu Méliès. A tragédia é que o fizemos, mas que não o posso abrir. Antes, havia uma coleção permanente no segundo andar e, depois, a Galeria dos Doadores no terceiro. Juntámos tudo isso e fizemos o Museu Méliès. Restam ainda dois grandes projetos; o primeiro, que está em fase de conclusão, é Napoléon (Napoleão), do Abel Gance. ${ }^{18}$ Bem, essa pequena história começou em 1927; por isso, talvez possamos esperar que em 2021 ou 2022 lá cheguemos. Também tratei disso - Napoléon está quase pronto. Levounos algum tempo, mas tem uma duração de sete horas.

\footnotetext{
${ }^{16}$ A exposição "Tim Burton” (comissariada por Ron Magliozzi e Jenny He) teve lugar na Cinémathèque française entre 7 de Março e 5 de Agosto de 2012.

${ }^{17}$ Henri Langlois (1914-1977) foi um pioneiro na conservação de filmes e co-fundou a Cinémathèque française em 1936.

${ }^{18}$ O projeto Napoléon foi a obra-prima de Abel Gance. Desde a primeira versão, em 1927, até às várias reedições sonoras que Gance propôs, em 1925, 1955 e 1971, o filme é uma espécie de aventura cinematográfica permanente. Cada versão ou restauração do filme gerou a criação de novos elementos (contratipos, elementos intermediários, cópias positivas) que, de certa forma, dificultaram muito a compreensão do que era o projeto do filme de 1927. Já na década de 1950, Gance tinha confiado a Henri Langlois os elementos do filme em sua posse. A Cinémathèque française estabeleceu assim a tarefa de reavivar a versão "Apollo" de 1927 (uma versão que foi exibida no cinema Apollo em Maio de 1927 e durou quase 10 horas), reunindo todo o material cinematográfico existente. Georges Mourier, realizador, investigador, especialista de Abel Gance, é o responsável pela restauração do filme.
} 


\section{MRG - É também um projeto complicado porque há a questão dos direitos do filme que estão espalhados entre diversas instituições e pessoas.}

FB - Tudo é complicado. Esse é o problema do filme desde o início. Para dizer a verdade, desde 1927 que é um filme monstruoso, não se pode explorá-lo. O cinema, quer se goste ou não, é assim: há sempre alguém que ganha ou perde dinheiro. Os franceses têm dificuldade em compreender isso porque temos um cinema subsidiado. Diz-se que Hollywood persegue este e aquele... Mas as pessoas, em Hollywood, perdem o seu dinheiro, não se riem. Não é o dinheiro do CNC. O cinema não é apenas uma arte industrial, é também uma arte comercial. É preciso compreender isso. O pobre Gance acaba com um filme gigantesco... É o culminar da sua carreira e o início de uma espiral descendente que, infelizmente, nunca terminará. Bem, talvez em 2021 ou 2022 cheguemos à versão mais completa do filme, quase um século após a filmagem. É muito tempo!

MRG - É um grande projeto.

FB - Oh, sim, é um belo projeto! E é, realmente, um filme sublime. Napoléon é extraordinário, muito mais do que uma obra-prima obrigatória, académica. É uma espécie de odisseia juvenil. É uma coisa louca de adolescente. É um filme experimental... Godard tem razão quando diz que é a infância da arte. Aqui, vemos a infância da arte. Por isso, é um projeto importante. Devemo-lo a Gance. De facto, na Cinémathèque, não devemos ir contra a história. Pode fazer-se tudo, mas é um erro ir contra a história. Langlois e Gance eram muito bons amigos apesar de tudo... Estamos a restaurar Napoléon e temos os direitos porque Langlois decidiu tratar desse filme. Temos de aceitá-lo; é uma herança muito boa. Não há qualquer problema em fazê-lo. Ao mesmo tempo, não nos devemos, naturalmente, iludir e sacralizar a figura de Langlois. De facto, é alguém que, como qualquer ser humano, teve períodos de glória, períodos de desastre, períodos em que esteve muito inspirado, períodos em que esteva menos inspirado. Langlois foi muito mais eficaz quando teve Malraux como amigo. ${ }^{19}$ Essa é a verdade. Mesmo que Malraux tenha errado ao decidir expulsá-lo da sua

\footnotetext{
${ }^{19}$ André Malraux (1901-1976) foi um escritor e intelectual francês que serviu como Ministro dos Assuntos Culturais entre 1959 e 1969.
} 
cinemateca. ${ }^{20}$ Mas, quanto aos anos que se seguiram a 1968, o mínimo que se pode dizer é que não foram gloriosos. Foi nessa altura que ocorreram os piores incêndios. Os nossos tesouros foram mal preservados porque já não restava um tostão a Langlois. Não obstante, somos responsáveis por aquilo que preservamos. Também somos julgados em função disso. E Langlois foi um génio na programação, um génio em geral, mas não deixou a casa em bom estado. Portanto, também temos de levar isso a sério: deixar a casa em boas condições.

MRG - Foi o que Dominique Païni ${ }^{21}$ também disse sobre Langlois: que ele era um poeta, não um administrador, nem um gerente.

FB - Sim... Há pessoas que ainda falam sobre isso. Tenho um bom amigo americano que era crítico no New York Times e agora trabalha no MoMA que ainda me diz: "foste tu que perdeste a segunda parte de The Wedding March ( A Marcha Nupcial), de Erich von Stroheim!”. Conhece esta história? O filme de Stroheim existia em duas versões: o filme que conhecemos e, depois, duas horas mais com o casamento. Desconheço a razão, mas, nos anos 50, o MoMA, enviou a sua única cópia ao Langlois... Queimou-se! O Langlois não o fez de propósito, coitado, mas a cópia ardeu. $\mathrm{O}$ nitrato ardeu. Nunca mais voltaremos a ver a segunda parte de The Wedding March, de Stroheim, e o MoMA continua a culpar-me. As cinematecas também têm essa responsabilidade.

\section{MRG - Falou há pouco de um segundo grande projeto...}

FB - O enorme trabalho em curso prende-se com as coleções da Cinémathèque française: são esplêndidas, mas, a dada altura, raiam o absurdo. Noutras palavras, permanecemos langloisianos, eu e todos os meus predecessores. Continuamos a manter, a preservar e a recolher, a inventariar tudo o que está à volta do cinema, ou seja, os arquivos. Não só guiões, cartazes, fotografias, desenhos, mas também elementos de décor, figurinos, projetores, máquinas fotográficas... Não há nenhuma

\footnotetext{
${ }^{20}$ Após uma série de tensões entre a supervisão ministerial (a Cinémathèque française é fortemente financiada pelo Ministério da Cultura através do CNC) e Henri Langlois, este último foi expulso da Cinémathèque a 9 de Fevereiro de 1968. Por um lado, o CNC procurava recuperar o controlo dos arquivos (mais ou menos bem geridos por Langlois), por outro lado, Langlois não aceitava a entrada de funcionários públicos zelosos próximos do Ministério no Conselho de Administração. Os adeptos da Cinémathèque, incluindo toda a geração da Nouvelle Vague, opuseram-se imediatamente ao afastamento de Langlois. Uma grande parte da cinefilia internacional foi mobilizada; Chaplin, Welles, Hitchcock e Lang expressaram publicamente a sua indignação. Após várias manifestações, Henri Langlois foi reintegrado a 22 de Abril de 1968. Para muitos, este "caso Langlois" foi uma espécie de preparação para os acontecimentos de Maio de 1968.

${ }^{21}$ Dominique Païni (n. 1947) é crítico de arte, curador de exposições e antigo diretor da Cinémathèque française entre 1991 e 2000.
} 
cinemateca no mundo que tenha tamanha coleção. Há algumas que têm mais filmes do que nós. Há quem saiba mais sobre o que tem do que nós... Mas ninguém tem uma tal diversidade de equipamentos cinematográficos nas suas coleções. É esse o génio de Langlois, compreendeu que, basicamente, a dada altura, os filmes iriam ser cada vez mais acessíveis a todos. O que é o caso, ainda que eu diga que nem todos os filmes serão digitalizados. Ao longo da história do cinema, os filmes nunca foram tão acessíveis quanto hoje. Isso é óbvio. Por outro lado, considerando os arquivos, há aqueles que têm tudo e aqueles que não têm nada. E nós temos tudo. Isso coloca-nos um problema: temos de mostrar o nosso arquivo. Mostramo-lo aos investigadores. A esse respeito, as coisas também melhoraram muito; a Cinémathèque já não é tanto uma fortaleza. Os nossos tesouros devem ser mostrados. É o nosso dever. Está tudo adormecido em caixas; por isso, temos de encontrar um lugar. Poderia ser fora de Paris, num espaço de, pelo menos, 3.000 metros quadrados, ou seja, seis vezes o quinto andar daqui, para fazer um museu. Custa bastante dinheiro e, portanto, requer vontade política. Uma vez terminado Napoléon, é o que se segue.

\section{MRG - Será um museu sobre a história do cinema?}

FB - Absolutamente. É um museu sobre a história estética do cinema e também, dadas as nossas coleções, sobre a história e a realização do cinema. Ambas estão obviamente ligadas: há uma Nouvelle Vague porque há câmaras ligeiras, etc.

\section{MRG - A exposição seria uma espécie de expansão daquela sobre “La Machine-cinéma”? ${ }^{22}$}

FB - Sim, absolutamente. Com “La Machine-cinéma” pudemos ver, por fim, as nossas coleções de máquinas, que são únicas! O único defeito dessa exposição (não era o seu defeito, mas a sua essência mesma) era que só havia máquinas. Quero mostrar tudo de uma só vez. Haverá máquinas, documentos, figurinos, acessórios, ecrãs. Langlois tentou utilizar película de $16 \mathrm{~mm}$, mas nunca funcionou, porque, com $16 \mathrm{~mm}$, as lâmpadas partiam-se, etc. Contudo, o seu sonho era fazer um museu cheio de extratos de filmes. Agora, com o digital, é muito mais fácil. Por isso, o museu estará cheio de excertos e montagens e explicará a história do cinema, desde os primeiros truques ópticos do século XVIII,

\footnotetext{
${ }^{22}$ A exposição "De Méliès à la 3D: La Machine-cinéma" (comissariada por Laurent Mannoni) teve lugar na Cinémathèque française entre 5 de Outubro de 2016 e 29 de Janeiro de 2017.
} 
mesmo do século XVII, até aos nossos dias. E nós temos tudo isso, nós temos tudo isso. A questão é saber como mostrar os materiais e, acima de tudo, como mostrar os arquivos, isso é o principal... E como definir este museu, essa é uma questão importante. E como transmitir esta história do cinema a gerações que, afinal de contas, estão no YouTube e não têm necessariamente nada a ver com ela. Esse é o próximo desafio, um desafio custoso. Trata-se de um projeto caro e complicado para os próximos anos, juntamente com o projeto mais invisível de digitalização gradual das coleções de filmes. Igualmente dispendioso.

MRG - De todas as coleções?

FB - Não, nunca lá chegaremos. O mais importante é o seguinte: se tivermos uma cópia fotográfica sublime, mesmo de um filme muito famoso, vamos digitalizá-la. É melhor do que continuar a projetá-la, porque, se continuarmos a projetá-la, acaba por desintegrar-se. Compreendi isso muito rapidamente porque cheguei à Cinémathèque quando tinha 20 anos. Assim que se coloca uma cópia num projetor, esta danifica-se. É esse o drama do cinema. Uma das muitas tragédias do cinema.

MRG - Em relação às exposições futuras, também em termos de política, quais são as escolhas? Por exemplo, neste momento, a exposição Louis de Funès, que, infelizmente, foi interrompida pela pandemia, recebeu muito público?

FB - Sim, é uma pena porque a exposição funcionou bem. É engraçada, uma boa exposição. Vendeu 50 mil bilhetes muito rapidamente, apesar da sua capacidade ter sido limitada pelas restrições de combate à pandemia. A minha principal preocupação é reabri-la. Não sei quando... E também a de abrir o museu Méliès. Estou muito satisfeito com o museu. Muito orgulhoso! E, depois disso, temos alguns projetos engraçados, como a exposição "Moda e Cinema", com Jean-Paul Gaultier, no Outono. Depois, uma exposição dedicada a uma atriz, visto que Louis de Funès foi o nosso primeiro ator: Romy Schneider.

\section{Isso é para o próximo ano. O que se segue? Alguma proposta?}

FB - Depois... Depende também do que outros estão a fazer. Por exemplo, a exposição dedicada a Burton, um grande sucesso, foi comprada aos americanos. Há dois cineastas americanos, dois excelentes cineastas, que realmente se prestariam bem para uma exposição: Tarantino e Wes Anderson. Estamos a tentar Tarantino, mas não tenho a certeza se ele entende exatamente do que estamos a falar, 
porque as exposições cinematográficas são uma coisa muito francesa. Não existem em todos os países. Gostava de ver uma exposição dedicada ao Tarantino. Seria engraçada: pareceria uma garagem, com todos os seus carros. E Wes Anderson é óbvio, mas talvez alguém a faça antes de mim. É tão óbvio... E ele é, realmente, um grande cineasta.

MRG - Estávamos a começar a falar sobre a reabertura... Os cinemas são atualmente obrigados a permanecer fechados por causa da pandemia. Qual é o impacto desta situação na Cinémathèque?

FB - Há duas coisas. Penso que reagimos muito bem porque criámos a plataforma "Henri". ${ }^{23}$ Contudo, não devemos esquecer algo: podemos fazer o que quisermos, mas nunca teremos os direitos dos filmes. Só podemos reproduzir na plataforma "Henri" os filmes raros cujos direitos detemos ou que obtemos pelo tempo da sua emissão. "Henri" é, realmente, uma plataforma destinada a coleções de filmes e eu queria que permanecesse livre e acessível. Para dizer a verdade, estamos repletos de projetos. Não sabemos como o vamos fazer. Mostrámos uma pequena parte das coleções de filmes na "Henri". Devemos mostrar também uma pequena parte das coleções de arquivos noutro lugar, num site que seria um complemento da "Henri" para os arquivos.

MRG - Por exemplo, para poder ver guiões, fotos, etc.?

FB - Sim. Amanhã vou ver os dois álbuns fotográficos de Napoléon. Parece que são espetaculares! Somos os únicos que os temos. Comprámos o script do filme Faust: Eine deutsche Volkssage (Fausto) de Murnau. Pode imaginar... Comprei um arquivo incrível sobre toda a história de L'Âge d'or (A Idade de Ouro), de Luis Buñuel, no Studio 28. Agora, está tudo na Cinémathèque, à disposição dos investigadores, mas podíamos filmá-lo, mostrá-lo um pouco. Estamos a tentar encontrar uma maneira de o fazer. Laurent Mannoni ${ }^{24}$ tem um modelo de câmara cujo lindo resultado foi o incêndio do Bazar de la Charité, em 1897, onde várias dezenas de pessoas foram queimadas vivas. Não vamos repeti-lo, mas temos a máquina! É uma loucura, uma loucura... E

\footnotetext{
23 "Henri" é uma plataforma VOD lançada a 9 de Abril de 2020 pela Cinémathèque française, que tinha sido fechada a 13 de Março de 2020 como parte das medidas de contenção adotadas pelo governo francês para combater o avanço da pandemia COVID-19. Esta plataforma oferece gratuitamente, em alta-definição, filmes raros das coleções da Cinémathèque française ou dos seus parceiros. Encontra-se acessível neste endereço: https://www.cinematheque.fr/henri/

${ }^{24}$ Laurent Mannoni (n. 1966) é colecionador, cineasta e escritor, especializado na pré-história do cinema. É $o$ diretor do património da Cinémathèque française e do Conservatoire des techniques cinématographiques.
} 
nem sequer estou a falar de coisas óbvias como os cartazes. As coleções desta casa são uma loucura. Portanto, é óbvio que não podemos mostrar tudo. Será sempre para investigadores, para consulta, mas vamos, pelo menos, mostrar algumas delas.

MRG - Durante este período de sucessivos confinamentos, pensa que a Cinemateca - como tem sido frequentemente comentado nos últimos anos - tem um papel cultural e social?

FB - Claro que temos um papel cultural e social, mas esse papel não pode ser... Quer dizer, só podemos dar aquilo que temos... E dar o que temos são as coleções. Como na plataforma "Henri". Disponibilizar o material ao público gratuitamente, com o acompanhamento que lhe está associado. Agora, para responder à sua pergunta: para lhe dizer a verdade, não estou muito preocupado connosco. Noutras palavras, somos tão singulares que as pessoas voltarão sempre. Não estou preocupado. As pessoas voltarão. Penso mesmo que voltarão em massa. A Cinémathèque não tem, realmente, um problema de público. E, muito honestamente, com toda a imodéstia, tem ainda menos problemas nos últimos cinco anos. Agora, quer o cinema francês, quer o cinema mundial - o que vai muito além da pequena Cinemateca Francesa - voltará exatamente ao mesmo nível de antes. Não sabemos quanto tempo demorará... Ninguém pode responder a essa pergunta. Dito isto, não estou muito pessimista. Vimos que, quando as salas de cinema reabriram, ainda que sem os filmes americanos, com exceção de Tenet, as pessoas voltaram. As salas não estiveram vazias quando reabriram. Penso que o cinema é uma arte performativa, que as pessoas, mesmo com o peso da Netflix, vão voltar. Sou o primeiro assinante da Netflix e eles são nossos parceiros, não são nossos inimigos. Também vejo The Crown na Netflix, mas isso não me faz deixar de querer ver filmes nos cinemas.

MRG - Então, pensa que existe uma possível complementaridade?

FB - Complementaridade não sei, porque também não são só bons rapazes; continuam a ser homens de negócios. Penso que o cinema como espetáculo coletivo, como forma de sair de casa, não está morto. Não creio que uma pandemia mate isso. Quanto à Cinémathèque, o que oferecemos nos nossos ecrãs é muitas vezes inédito. Não estou nada preocupado. 


\section{MRG - Também em termos de educação, como agir tendo em conta as gerações futuras? Como mobilizá-las para que compreendam que ver filmes em $35 \mathrm{~mm}$ é algo especial?}

FB - Há algo que não voltará. Não sou um demagogo e também não sou estupidamente otimista. Ou seja, tenho 50 anos: penso ter conhecido o fim do momento em que o cinema estava no centro da sociedade. Estou disposto a admitir que isso não vai voltar. Quando olho para os meus filhos, eles estão mais interessados em videojogos e no YouTube. Não posso dizer o contrário. Agora, talvez o cinema venha a ser mais minoritário do que já é. Admito isso. Mas isso não significa que ninguém esteja interessado nele. Os nossos vizinhos são o MK2 Bibliothèque e o UGC Ciné-Cité Bercy, ${ }^{25}$ eles são nossos amigos. Estou sempre no MK2 ou no UGC. Francamente, não vejo apenas idosos aos fins-de-semana. As salas do MK2 estão cheias de crianças dos subúrbios. Talvez demore algum tempo a recomeçar. Talvez algumas estruturas desapareçam. Não sei. Talvez o sistema mude. Teremos de nos dar bem com as plataformas. Além disso, eu era jovem nos anos 80 . Há trinta anos que ouço falar da morte do cinema. Daney falou durante dez anos sobre a morte do cinema, falou da sua própria morte, o que é muito compreensível e humano: foi um grande crítico de arte. Era suposto que o VHS matasse o cinema, mas foi este que morreu. Depois, o DVD deveria ter matado o cinema e também foi o DVD que morreu. Agora, são as plataformas que vão matar o cinema ao comprar catálogos... Veremos. Francamente, penso que não. Já ouvi falar tanto disto... Ao mesmo tempo, há uma revolução epistemológica; seria absurdo negá-lo. É por isso que falo muito facilmente com a Netflix, mas não estamos no mesmo ramo. Pode imaginar, tenho 400 lugares nas nossas salas de cinema, mas, só em França, a Netflix tem 7 ou 8 milhões de assinantes. Não estamos na mesma escala. Temos de nos habituar à ideia de que estamos em minoria. Eu lido com cinema e, além disso, com filmes antigos, como as pessoas dizem... Depois, num sábado à noite, quando mostramos Rosemary's Baby (A Semente do Diabo), criticam-nos por outras razões, ${ }^{26}$ mas o cinema está cheio e os jovens estão histericamente entusiasmados, juntam-se, em grupos. Não

\footnotetext{
${ }^{25}$ Nomes de dois multiplexes de cinema perto da Cinémathèque française, em Paris.

${ }^{26}$ Frédéric Bonnaud refere-se aqui, sem dúvida, à controvérsia que teve lugar no final de 2017 quando, em pleno caso Harvey Weinstein, nos EUA, muitas vozes se levantaram para criticar o convite feito a Roman Polanski- realizador de, entre outros filmes, Rosemary's Baby - durante uma retrospetiva da sua obra, em Novembro desse ano.
} 
estou nada desesperado. Por outro lado, noto que os três grandes filmes americanos recentes são: Once Upon a Time in Hollywood (Era Uma Vez em... Hollywood), de Quentin Tarantino, The Irishman (O Irlandês), de Martin Scorsese, e Mank, de David Fincher. A Netflix não tem nada a ver com o primeiro. No caso dos outros dois, dois grandes cineastas americanos trabalham com a Netflix porque podem obter um orçamento ilimitado e o final cut. Por outras palavras, o que eles dão a Scorsese e Fincher é o que Hollywood deu uma vez a Welles. Uma vez! Não é por isso que eles são necessariamente filantropos, não sou estúpido, mas, sem eles, não haveria The Irishman ou Mank.

\section{MRG - Talvez uma última pergunta... Mencionou brevemente Oliveira - tem uma relação particular com o cinema português?}

FB - Cheguei na altura certa. Ou seja, Paulo Branco estava muito ansioso por ser reconhecido pelo mundo cinematográfico no fim dos anos 70 e 80. Queria ser reconhecido pelo Daney. Sou 20 anos mais novo do que ele. Tornámo-nos amigos muito facilmente e não só porque ele é uma pessoa com muita lábia e um sedutor, mas também porque fiquei espantado com o que ele estava a produzir. É essa a minha relação com Portugal. Muito honestamente, é através do Branco, porque é verdade que ele assegurou a continuidade da produção de Oliveira... Quando vi Vale Abraão, foi em 1993 e ainda não era um crítico, fiquei rendido. É realmente um dos dez filmes mais bonitos do mundo. Assim, inevitavelmente, o tipo que produziu Oliveira, o tipo que produziu Monteiro, que, além disso, teve cinemas, que produziu autores franceses, isso criou em mim uma ligação muito forte com Portugal. E o que é engraçado (bem, ele não o acha engraçado) é que devíamos ter feito a sua segunda retrospetiva. Estava agendada para Fevereiro de 2020. Vai ser adiada, mas Dominique Païni, um dos meus mais brilhantes antecessores, fê-lo nos anos 90, pelo que teria sido a segunda retrospetiva de Branco. Agora, não tenho um conhecimento enciclopédico do cinema português, mas conheço um pouco... Mais os antigos do que os novos, para ser honesto. O jovem cinema português não é de todo a minha especialidade, mas porque já não vou a festivais. Quando se vai a festivais, vêm-se sempre novos cineastas a chegar. Quando se deixa de ir, perde-se rapidamente o rumo. Estou um pouco dececionado com Miguel Gomes. Devo dizer que preferia Aquele Querido Mês de Agosto. A sua trilogia das Mil e Uma Noites não me parece muito boa. Acho-o ligeiramente sobrestimado, devo dizer, o que não significa que o odeie de todo. Pelo contrário, tinha visto uma das 
suas primeiras curtas-metragens, uma história sobre pessoas em piscinas. Foi no Festival de Turim há muito tempo e não consegui darlhe o prémio porque estava isolado. Deve ter sido a sua primeira curtametragem, chamava-se Contratempo, ${ }^{27}$ algo do género... Esqueci-me... O cinema dele tem algo, mesmo que eu prefira a primeira longametragem. Nem mesmo tenho visto os filmes de Pedro Costa porque, por razões por mim desconhecidas, já não são distribuídos em Paris. Antes, costumava vê-los em festivais e gostava muito.

MRG - Esteve recentemente em Portugal. Podemos falar de relações entre a Cinémathèque française e outras cinematecas? Ou, mesmo, de uma maneira geral, a Cinémathèque está ligada a outras instituições?

FB - A nossa relação com as outras cinematecas é excelente. Agora, em comparação com os anglo-saxões, haverá sempre alguma coisa estranha. Faz-me rir. É a vida, o folclore das cinematecas. A pessoa que dirige, imaginemos, o BFI ou os arquivos na Suécia, deve pensar que os franceses, Païni, Toubiana, Bonnaud, todos esses, não são sérios, percebe o que quero dizer... Ou seja, em comparação com os anglosaxões, que são puros arquivistas, seremos sempre vistos como brincalhões, mas não é nada de grave. Tem a ver com o Langlois... Mais uma vez, as relações acalmaram-se, trocamos cópias, está tudo bem, mas acho que eles não compreendem o que eu faço. E eu não compreendo o que eles fazem. Com a Filmoteca de Madrid ou a Cinemateca de Lisboa não é de todo o mesmo, mas com os anglosaxões, sim, pode sempre haver um pequeno mal-entendido, é possível. Com o Langlois foi uma guerra. Talvez também passe por uma diferente relação com o público. É verdade que sou um crítico de cinema. E que sou mais um propagador... É uma diferença de cultura e de tradição. Penso que as opiniões se tornaram bastante próximas... Eles tendem a ser arquivos em primeiro lugar, mas, para mim, o importante é o público. Que tenhamos um arquivo aberto. Para nós, isso é o principal.

${ }^{27}$ Frédéric Bonnaud refere-se, provavelmente, ao filme Entretanto (1999). 


\section{'For me, the important thing is the audience': Interview with Frédéric Bonnaud, director of Cinémathèque française}

A BSTRACT Frédéric Bonnaud has been director of the Cinémathèque française since 2016. Before that, he was a journalist and film critic. During the interview conducted on January 20, 2021 at the Cinémathèque, Frédéric Bonnaud spoke of his relationship with this institution, cinema and cinephilia. Generous and optimistic, he addressed the projects and challenges of the Cinémathèque française for the coming years, while reflecting on the particular situation of crisis that the professions linked to cinema are going through.

KEYWORDS Curatorship; Frédéric Bonnaud; Cinémathèque française; COVID-19; film digitalization; exhibitions; history of cinema. 